\title{
Spatial distribution of toxic Alexandrium tamiyavanichii (Dinophyceae) in the southeastern South China Sea-Sulu Sea: A molecular-based assessment using real-time quantitative PCR (qPCR) assay
}

\author{
Nyuk Fong Kon ${ }^{\mathrm{a}}$, Sing Tung Teng ${ }^{\mathrm{b}}$, Kieng Soon Hii ${ }^{\mathrm{a}}$, Leh Hie Yek ${ }^{\mathrm{a}}$, Aazani Mujahid ${ }^{\mathrm{b}}$, \\ Hong Chang Lim ${ }^{\mathrm{c}}$, Po Teen $\operatorname{Lim}^{\mathrm{c}}$, Chui Pin Leaw ${ }^{\mathrm{c}, *}$ \\ ${ }^{a}$ Institute of Biodiversity and Environmental Conservation, Universiti Malaysia Sarawak, 94300 Kota Samarahan, Sarawak, Malaysia \\ ${ }^{\mathrm{b}}$ Faculty of Resource Science and Technology, Universiti Malaysia Sarawak, 94300 Kota Samarahan, Sarawak, Malaysia \\ ${ }^{\mathrm{c}}$ Institute of Ocean and Earth Sciences, University of Malaya, 16310 Bachok, Kelantan, Malaysia
}

\section{A R T I C L E I N F O}

\section{Article history:}

Received 27 January 2015

Received in revised form 2 October 2015

Accepted 2 October 2015

Available online 26 October 2015

\section{Keywords:}

Alexandrium

Detection

Malaysian Borneo

Paralytic shellfish poisoning

Saxitoxin

Second internal transcribed spacer

\begin{abstract}
A B S T R A C T
In this study, a quantitative real-time PCR (qPCR) assay targeting the second internal transcribed spacer (ITS2) of the nuclear-encoded ribosomal RNA gene (rDNA) was developed for Alexandrium tamiyavanichii, a harmful tropical marine dinoflagellate. This species is of concern because it produces toxins that cause paralytic shellfish poisoning (PSP). The qPCR assay employed hydrolysis probe technology and showed high specificity, with a detection limit of $10^{2}$ gene copies (less than one cell equivalent). Using this assay, the spatial distribution of A.tamiyavanichii was assessed, for the first time, in the southeastern South China Sea and the Sulu Sea. Plankton samples were collected from 71 stations during a scientific cruise from the Research Vessel Sonne as part of the joint EU project on Stratosphere ozone: Halogens in a Varying Atmosphere (SHIVA), conducted in November 2011. The highest cell densities were detected offshore of Kuching, southern Borneo (150 cells $\mathrm{l}^{-1}$ ) and exceeded the threshold level of 20-40 cells $1^{-1}$ where the bioaccumulation of PSP toxins by shellfish is of concern. The distribution of $A$. tamiyavanichii was patchy horizontally with the highest cell concentrations found mainly offshore of southern Borneo, and a heterogeneous vertical distribution was observed above the pycnocline. The A. tamiyavanichii qPCR assay proved its applicability, specificity and sensitivity, and provides an alternative implementation tool for harmful microalgae monitoring programs.
\end{abstract}

(C) 2015 Elsevier B.V. All rights reserved.

\section{Introduction}

The South China Sea (SCS), located in the equatorial Western Pacific Ocean, one of the world's busiest shipping transition points, is not only ecologically important with its tremendous marine biodiversity and diverse ecosystems, but is also rich in its fisheries resources. The utilization of those resources has expanded rapidly over the past decade, as the Southeast Asian countries surrounding the SCS have experienced the greatest annual increase in harvests of cultured and wild-caught fish worldwide between 2008 and 2012 (SEAFDEC, 2014). The regional investment in fish aquaculture has been particularly intensive and now accounts for a majority of global production (i.e., 53.3\% in 2012; SEAFDEC, 2014). The rigorous fish cultivation operation in Southeast Asia, however, has been accompanied by significant ecosystem deterioration

\footnotetext{
* Corresponding author. Tel.: +60 97785001; fax: +60 97785006.

E-mail addresses: cpleaw@um.edu.my, chuipinleaw@gmail.com (C.P. Leaw).
}

(Chua et al., 1989), including coastal eutrophication. The increased number of fish farms compared to a decade ago has contributed to high nutrient levels in the coastal waters. Among the many adverse effects from high nutrient inputs is the promotion of harmful algal blooms (HABs) (Smayda, 1990; Hallegraeff, 1993; Gilbert et al., 2005a; Glibert et al., 2010; Anderson et al., 2008). The blooms produce adverse shifts in phytoplankton species composition, toxins that kill or impair many species and excess biomass that promotes development of hypoxic conditions (Sunda et al., 2006).

Over the past four decades, the region investigated in this study has been particularly susceptible to dinoflagellate blooms that produce paralytic shellfish toxins (PSTs) associated with paralytic shellfish poisoning (PSP) (reviewed in Usup et al., 2012). Until 1970 , PSP was confined only to the temperate waters of Europe, North America and Japan (Dale and Yentsch, 1978), but was subsequently dispersed throughout the Southern Hemisphere (Hallegraeff, 1993), including the SCS (Usup et al., 2012). The main source of PSTs in the Southeast Asian waters is the toxic marine dinoflagellate, Pyrodinium bahamense var. compressum. In 